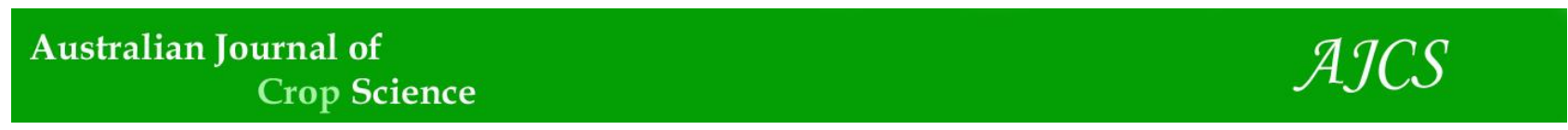

AJCS 15(10):1325-1331 (2021)

ISSN:1835-2707

doi: 10.21475/ajcs.21.15.10.p3291

\title{
Cassava yield indicators and total organic carbon in tropical soils under different fertilization treatments
}

\author{
Marcelo Laranjeira Pimentel ${ }^{1}$, Iolanda Maria Soares Reis ${ }^{2 *}$, Jailson Sousa de Castro ${ }^{3}$, Victor Sousa \\ Portela², Maria Lita Padinha Correa Romano ${ }^{2}$, Carlos Ivan Aguilar Vildoso ${ }^{2}$, Eloi Gasparin ${ }^{2}$, Eliandra Freitas \\ de $\mathrm{Sia}^{2}$
}

\author{
${ }^{1}$ Faculty of Agrarian and Veterinary Sciences, Paulista State University, Jaboticabal, SP, Brazil \\ ${ }^{2}$ Federal University of Western Pará, Santarém, PA, Brazil \\ ${ }^{3}$ Department of Plant Biology, Federal University of Viçosa, Viçosa, MG, Brazil
}

*Corresponding author: iolanda.reis@ufopa.edu.br

\begin{abstract}
Cassava is a crop of major socioeconomic importance in Brazil because of its versatility and high yield in nutrient-poor soils. Fertilization can improve soil quality and further increase cassava yield. This study aimed to investigate the effects of different fertilizer sources on soil total organic carbon (TOC) and cassava yield indicators. The experiment was conducted on a family farm in Santarém, Brazil, in a randomized block design, with four treatments and five replications. Treatments were as follows: T1, unfertilized soil (control); T2, NPK fertilizer; T3, poultry manure; and T4, cattle manure. The variables analyzed were soil TOC, shoot fresh weight, plant height, marketable stem diameter, marketable root yield, and yield. Data were subjected to analysis of variance, Tukey's test $(p<0.05)$, hierarchical clustering, and principal component analysis. Application of organic fertilizers (T3 and T4) increased soil TOC levels. Chemical fertilizer treatment (T2) resulted in the highest shoot fresh weight, yield, and marketable root yield. Marketable stem diameter was positively influenced by T2 and T4. There were no significant treatment effects on plant height. Hierarchical clustering isolated organic fertilizers (T3 and T4) from other treatments. Principal component analysis revealed two principal components, which together explained $87.77 \%$ of the total variance. Organic fertilizer application provided the highest TOC accumulation during the experimental period, whereas NPK fertilization was the most effective in increasing cassava yield in the first year of cultivation.
\end{abstract}

Keywords: organic fertilizer; cattle manure; organic matter; Manihot esculenta; crop yield.

Introduction

Cassava (Manihot esculenta Crantz) is a root crop belonging to the family Euphorbiaceae and characterized by a variable number of roots containing glycosides and latex (Alves, 2002). The crop has great economic and social importance because of its carbohydrate-rich roots, which serve as a staple food for millions of people worldwide (Guimarães et al., 2017; Utsumi et al., 2019).

Cassava shows high adaptability to different climates and is cultivated and consumed in several countries, particularly in low- and middle-income countries of Africa, Asia, and Latin America (Vieira et al., 2013; Pacheco et al., 2020). Cassava plants are also used as animal feed (Souza et al., 2019) and are considered one of the five most important commodities in bioethanol, biogas, and biodiesel production (Bezerra et al., 2019).

In Brazil, cassava is mostly produced on small family farms (Tironi et al., 2015) and holds great agronomic, sociocultural, and economic relevance throughout the country, particularly in the Amazon region. Family farming is estimated to account for $87 \%$ of the national production of cassava, meeting most of the local demand (FAO, 2016).

In 2018, global cassava production reached 277.8 million tonnes and a harvested area of 24.6 million hectares. In 2019,
Brazil was the fifth largest producer, with 17.49 million tonnes and 1.25 million hectares harvested (FAO, 2020; IBGE, 2020). Although Pará State is the largest national producer, it has fallen behind in crop yield as a result of inadequate management and inherently poor soil conditions, such as low soil $\mathrm{pH}$ and reduced nutrient availability. These limitations can be easily mitigated by application of organic or chemical fertilizers during the crop cycle (Pimentel et al., 2020).

Organic fertilizers not only supply nutrients but also increase carbon stocks in the soil profile, offering an advantage over chemical fertilizers (Malta et al., 2019); that is, organic fertilizer application can contribute to both crop and soil quality (Leite et al., 2003). Few studies have sought to identify associations between fertilizer sources, soil organic carbon, and cassava crop indicators.

The quality, quantity, and dynamics of soil organic carbon influence several plant functions (Lal, 2016). Therefore, understanding and monitoring the availability of soil organic carbon is crucial to improve soil management and increase crop yields. Such information is even more critical in tropical regions subject to rapid organic matter degradation and leaching loss (Senesi et al., 2016). 
This study aimed to assess the effects of different fertilizer sources on soil total organic carbon (TOC) and agronomic characteristics of cassava grown on a family farm.

\section{Results and discussion}

\section{TOC analysis}

Soil TOC contents at the $0.0-0.2 \mathrm{~m}$ depth differed according to fertilization regime. Unfertilized soil (T1) differed in TOC level from soil treated with chemical or organic fertilizers (T2, T3, and T4), which did not differ from each other (Fig. 3). Biratu et al. (2019) studied the effects of chemical and organic fertilization on cassava cultivation and obtained similar results to those reported here: soil TOC content was found to be influenced by the use of organic fertilizers.

Lack of soil nutrient replacement, associated with inadequate crop management, may result in biomass loss, reduction of organic matter input, and, consequently, TOC loss. Denardin et al. (2014) observed that inadequate soil management and changes to cover crops may lead, in a short time, to losses of soil carbon stocks. The soil plays a key role in carbon sequestration; thus, such alterations can enhance soil carbon emission, thereby increasing the environmental impacts of greenhouse gases (Vieira et al., 2015).

Cattle manure (T4) was the most effective in increasing carbon input to soil compared with the control. Such a result is likely related to the high cellulose and lignin contents of cattle manure, which hinder microbial decomposition of organic matter. Ramos et al. (2016) reported that lignin and cellulose, unlike hemicellulose, have a low decomposition rate, resulting in a greater accumulation of organic matter in soil pores. Organic matter accumulation is mainly observed in clay soils, characterized by a high concentration of micropores.

According to Wiesmeier et al. (2019), soil texture (sand, silt, and clay proportions) is one of the most important factors for carbon accumulation in soil. The soil of the study area had a very clayey texture. An important effect of clay is the physical protection it confers to carbon, promoted by adsorption of organic compounds within pores, preventing microbial decomposition (Kravchenko and Guber, 2017). Because manure organic matter is not easily degraded by microorganisms, much of its carbon is retained and accumulates in clay micropores.

Carbon stabilization in soil is a result of the entry and exit of organic material (Chenu et al., 2019). A net gain or loss of soil carbon, in turn, is associated with the balance between microbial decomposition of carbon inputs and protection of this organic residue in the form of plant compounds or microbially processed carbon (Barré et al., 2018). The decomposition rate of organic carbon depends on the mechanisms of organic matter protection, which, according to Lützow et al. (2006), include recalcitrance, associated with the molecular weight of the residue; physical protection, determined by the spatial inaccessibility of microorganisms to organic matter; and complexation, that is, organomineral interactions with soil mineral surfaces. Therefore, carbon accumulation from organic fertilization is closely related to mechanisms of organic matter protection.

Compared with T1, T4 afforded a gain in soil TOC of $2.13 \mathrm{~g} \mathrm{~kg}^{-1}$ in only one crop cycle, corresponding to a TOC increase of 9.70\%. Cattle manure (T4) efficiently increased soil carbon content in a short period. Cattle manure fertilization may be particularly important in tropical climate regions, where organic matter decomposition rates are high (Barbieri et al., 2013).

Soil treated with poultry manure (T3) did not differ in TOC content from soil treated with cattle manure (T4); however, $\mathrm{T} 3$ values were numerically lower than those of $\mathrm{T} 4$ and similar to those of T1. Poultry manure contains large amounts of easily degradable compounds (sugars, amino acids, proteins), contributing to the rate of organic matter mineralization and, thereby, reducing carbon accumulation (Shah et al., 2013).

Overall, the results showed that fertilization, whether organic or chemical, positively influenced soil TOC levels. We highlight, however, that organic sources are low cost and highly efficient in increasing soil organic matter. According to Ghosh et al. (2018), organic fertilizers can improve soil structure because of the aggregation power of organic matter.

\section{Agronomic characteristics}

Cassava shoots fresh weight, encompassing leaves, stem, and branches, differed significantly between treatments. The parameter was highest for plants treated with chemical fertilizer (Fig. 4A). The use of nitrogen, phosphorus, and potassium (NPK) fertilizer (T2) resulted in a shoot fresh weight of $21.73 \mathrm{~kg} \mathrm{ha}^{-1}$, whereas lack of fertilization resulted in a shoot fresh weight of $16.53 \mathrm{~kg} \mathrm{ha}^{-1}$.

Such a result can be attributed to high nutrient availability, given that chemical fertilizers are readily available in soil, increasing nutrient absorption by plants. As discussed by Pereira et al. (2012), high cassava shoot development is associated with high macronutrient availability, particularly that of phosphorus. Phosphorus is of extreme importance for biochemical reactions, and its deficit impairs plant functions. High shoot fresh weight also indicates a higher leaf area index, which contributes to the production of photoassimilates and their translocation to plant organs.

Similar results were obtained by Alves et al. (2012) regarding NPK fertilization. The authors tested different NPK doses on cassava grown in Mojú, Pará State, Brazil, and observed that, when applying $600 \mathrm{~kg} \mathrm{ha}^{-1}$ NPK, the shoot fresh weight was $20.11 \mathrm{~kg} \mathrm{ha}^{-1}$; lack of fertilization resulted in a shoot fresh weight of only $13.08 \mathrm{~kg} \mathrm{ha}^{-1}$. In the current study, a higher shoot fresh weight was obtained, both with and without NPK fertilization.

Soares et al. (2019) argued that NPK fertilization can increase the shoot fresh weight of cassava, with the added benefit of minimizing losses related to weeds because of the higher soil coverage. Otsubo et al. (2012) underscored the importance of rapid cassava shoot development, which allows obtaining propagative material and animal feed in a short period.

Plant height did not differ significantly between treatments, although the variable was numerically higher in plants fertilized with cattle manure $(3.03 \mathrm{~m})$ and NPK $(2.98 \mathrm{~m})$; the lowest height was observed in unfertilized plants $(2.61 \mathrm{~m})$ and plants fertilized with poultry manure $(2.60 \mathrm{~m})$ (Fig. 4B). These results are in line with those described by Suárez and Mederos (2011), who reported that cassava plant height can range from 1 to $5 \mathrm{~m}$ but typically does not exceed $3 \mathrm{~m}$.

Plant height is an important factor, particularly for strong plants, as strong winds can lead to lodging. Rós et al. (2013) argued that cassava plant height must be considered when choosing crops for intercropping.

The diameter of marketable stems differed significantly between treatments (Fig. 4C). NPK and cattle manure treatments did not differ from each other and afforded higher means than the control and poultry manure fertilization. NPK 
Table 1. Chemical and physical properties of $0-20 \mathrm{~cm}$ depth soil before cassava cropping.

\begin{tabular}{|c|c|}
\hline Attribute & 0-20 cm depth soil \\
\hline $\mathrm{pH} \mathrm{H} \mathrm{H}_{2} \mathrm{O}$ & 6.1 \\
\hline $\mathrm{pH} \mathrm{CaCl} 2$ & 5.4 \\
\hline$P\left(\mathrm{mg} \mathrm{dm}^{-3}\right)$ & 4.0 \\
\hline $\mathrm{K}\left(\mathrm{mg} \mathrm{dm}^{-3}\right)$ & 43.9 \\
\hline $\mathrm{Ca}+\mathrm{Mg}\left(\mathrm{cmol}_{\mathrm{c}} \mathrm{kg}^{-1}\right)$ & 4.6 \\
\hline $\mathrm{Ca}\left(\mathrm{cmol}_{\mathrm{c}} \mathrm{kg}^{-1}\right)$ & 3.4 \\
\hline $\mathrm{Mg}\left(\mathrm{cmol}_{\mathrm{c}} \mathrm{kg}^{-1}\right)$ & 1.2 \\
\hline $\mathrm{Al}\left(\mathrm{cmol}_{\mathrm{c}} \mathrm{kg}^{-1}\right)$ & 0.0 \\
\hline $\mathrm{H}\left(\mathrm{cmol}_{\mathrm{c}} \mathrm{kg}^{-1}\right)$ & 4.0 \\
\hline Organic matter ( $\left.\mathrm{g} \mathrm{kg}^{-1}\right)$ & 37.8 \\
\hline Sum of bases $\left(\mathrm{cmol}_{\mathrm{c}} \mathrm{dm}^{-3}\right)$ & 4.8 \\
\hline Cation-exchange capacity $\left(\mathrm{cmol}_{\mathrm{c}} \mathrm{dm}^{-3}\right)$ & 8.7 \\
\hline Base saturation (\%) & 54.5 \\
\hline Al saturation (\%) & 0.0 \\
\hline Ca saturation (\%) & 39.0 \\
\hline Mg saturation (\%) & 14.3 \\
\hline K saturation (\%) & 1.3 \\
\hline $\mathrm{H}$ saturation (\%) & 45.5 \\
\hline $\mathrm{Ca} / \mathrm{Mg}$ & 2.7 \\
\hline $\mathrm{Ca} / \mathrm{K}$ & 29.8 \\
\hline $\mathrm{Mg} / \mathrm{K}$ & 11.0 \\
\hline Sand $\left(\mathrm{g} \mathrm{kg}^{-1}\right)$ & 173.0 \\
\hline Silt $\left(\mathrm{g} \mathrm{kg}^{-1}\right)$ & 168.0 \\
\hline Clay $\left(\mathrm{g} \mathrm{kg}^{-1}\right)$ & 659.0 \\
\hline
\end{tabular}

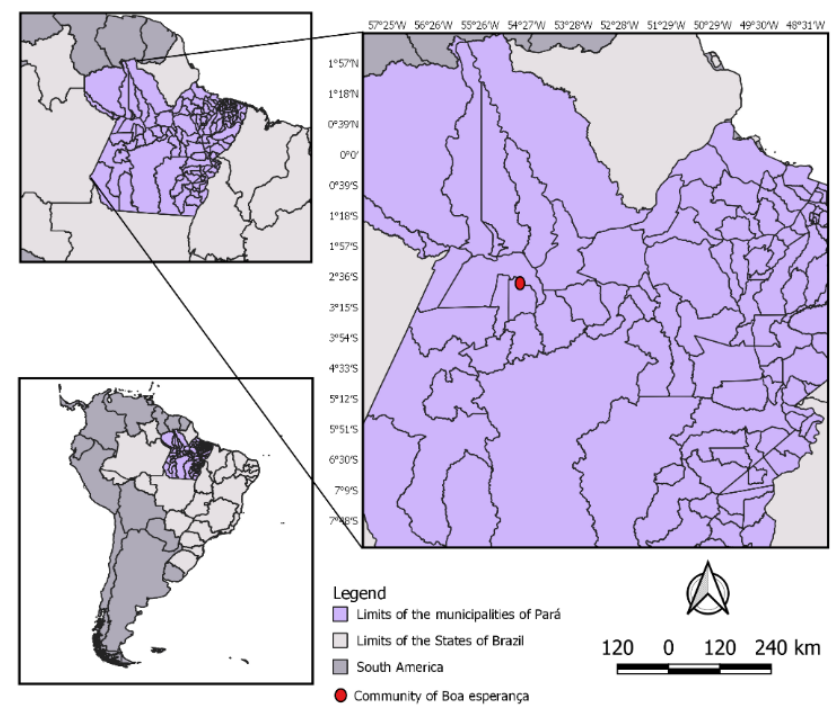

Fig 1. Experimental cassava cultivation on a family farm in the Boa Esperança community, Santarém, Pará, Brazil.

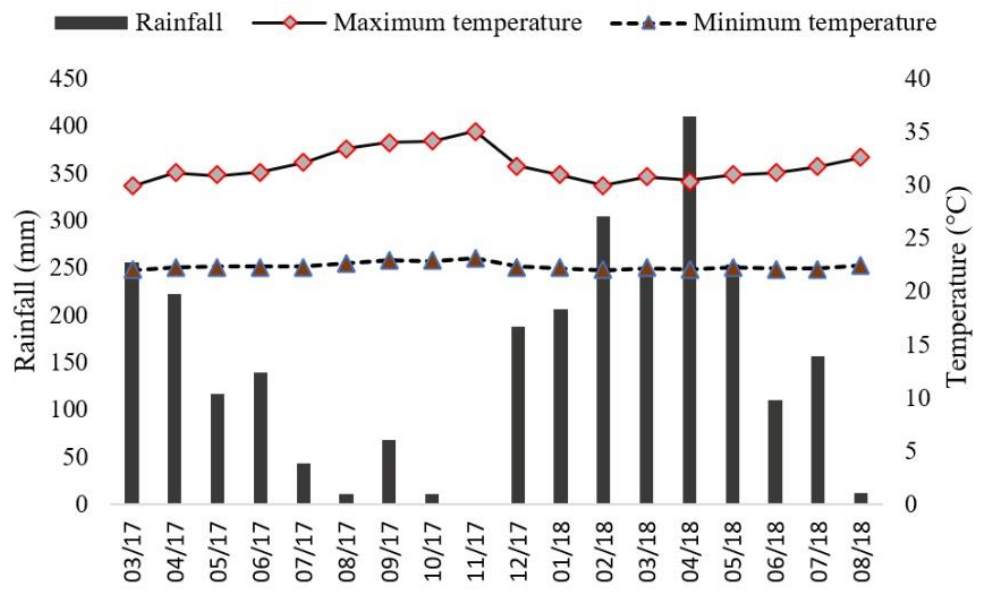

Fig 2. Rainfall and average maximum and minimum temperatures during the experimental period. 


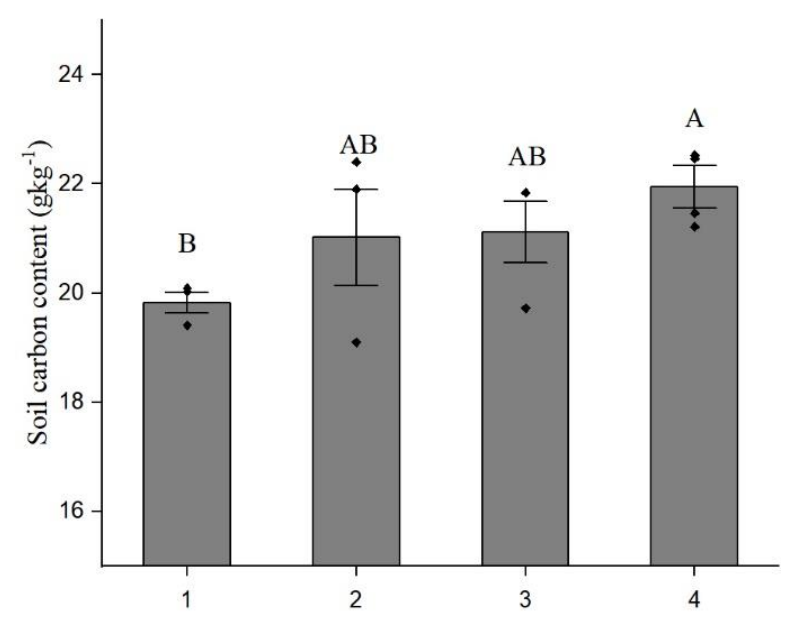

Treatments

Fig 3. Total organic carbon (TOC) content in unfertilized soil (T1) and soils fertilized with NPK (T2), poultry manure (T3), and cattle manure (T4). Means followed by the same letter are not significantly different by Tukey's test $(p<0.05)$. Outliers.
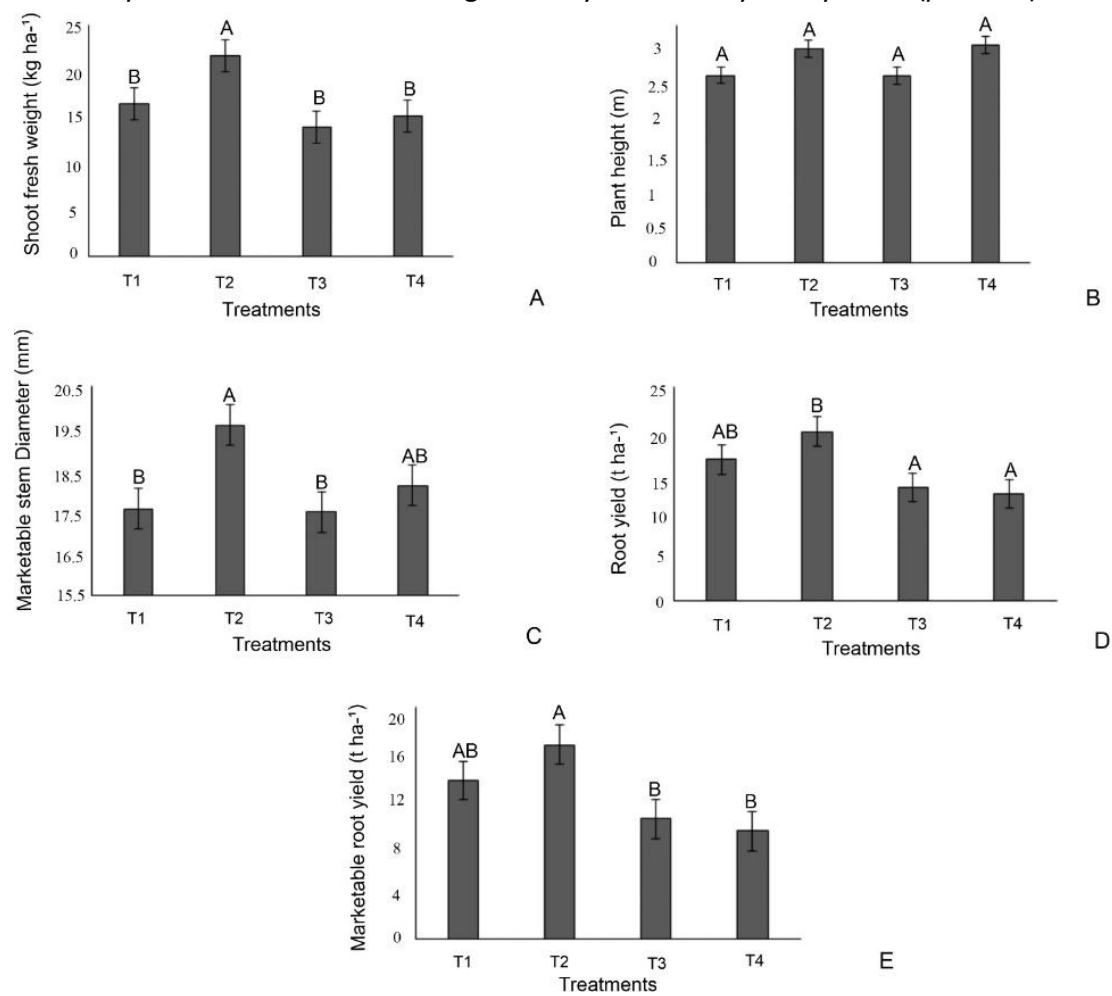

Fig 4. (A) Shoot fresh weight, (B) plant height, (C) marketable stem diameter, (D) root yield, and (E) marketable root yield of cassava grown on unfertilized soil (T1) and soils fertilized with NPK (T2), poultry manure (T3), and cattle manure (T4). Means followed by the same letter are not significantly different by Tukey's test $(p<0.05)$.
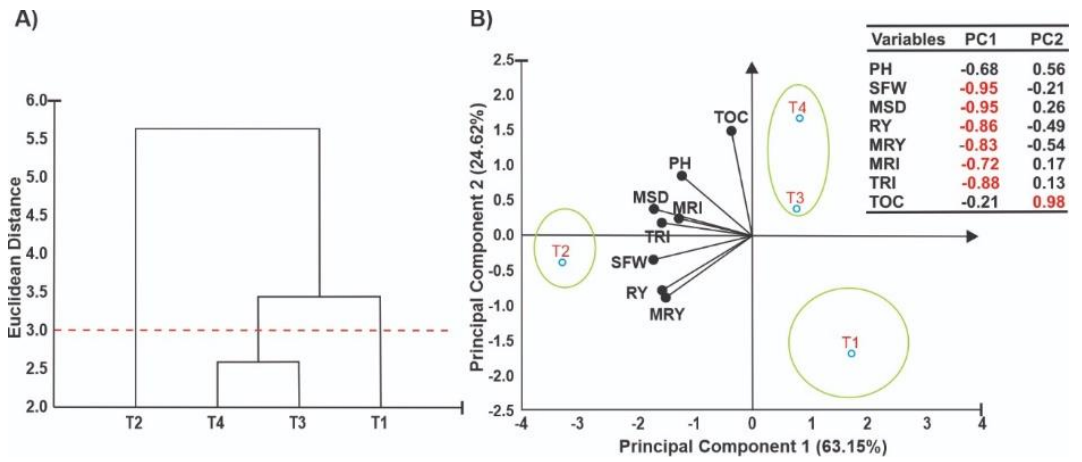

Fig 5. (A) Dendrogram and (B) PCA biplot of cassava plant height (PH), shoot fresh weight (SFW), marketable stem diameter (MSD), root yield (RY), marketable root yield (MRY), marketable root index (MRI), total root index (TRI), and soil total organic carbon (TOC). T1, unfertilized soil (control); T2, NPK fertilizer; T3, poultry manure; and T4, cattle manure. 
fertilization increased stem diameter by $2 \mathrm{~mm}$ compared with the control, representing an increase of $10.2 \%$, whereas cattle manure fertilization increased stem diameter by $0.56 \mathrm{~mm}$ (3.08\%). The high increase in stem diameter (10.2\%) promoted by NPK fertilization can be attributed to adequate potassium supply and the high vigor of cassava cuttings. Silva et al. (2017) observed an increase of $2.27 \mathrm{~mm}$ in stem diameter by fertilizing with $240 \mathrm{~kg} \mathrm{ha}^{-1} \mathrm{~K}_{2} \mathrm{O}$, in agreement with the findings of the current study. Overall, the results showed that NPK was effective in increasing nutrient availability, as it is a source of readily available nutrients, positively influencing shoot development, photoassimilate synthesis and conversion, and cutting yield.

NPK fertilization also significantly enhanced root yield, whereas poultry manure, cattle manure, and the control did not differ significantly from each other (Fig. 4D). Compared with the control, NPK fertilizer increased total root yield by $3.29 \mathrm{t} \mathrm{ha}^{-1}$ (16.59\%), from 16.53 to $19.82 \mathrm{t} \mathrm{ha}^{-1}$.

Falqueto et al. (2009) argued that an increase in shoot fresh weight is indicative of an increase in photoassimilate synthesis. As plants grow, photoassimilates are translocated from the leaves to other plant organs, such as the roots. Unfertilized plots had the second-highest yield, indicating that there might have been an excessive amount of organic fertilizers. Rós et al. (2020), in studying the effects of organic fertilization on cassava, found that excessive fertilization decreased yield; yield was highest when using $8 \mathrm{t} \mathrm{ha}^{-1}$ poultry manure, decreasing at higher fertilizer doses.

Cattle manure fertilization did not increase yield in the first crop cycle likely because of its low organic matter decomposition rate and, consequently, slow nutrient release. By contrast, Mathias and Kabambe (2015) found that cattle manure increased cassava yield by $26 \%$ compared with nonfertilization. Odedina et al. (2011) found that poultry manure was more effective in increasing yield than NPK fertilizer. Marketable root yield was lower in plants treated with organic fertilizers than in unfertilized plants and plants fertilized with NPK, which did not differ from each other. This result was expected, given the results of root yield (Fig. 4E). Although differences were not significant, NPK fertilization increased marketable root yield by $18.24 \%$ (16.77 t ha-1) compared with the control.

Cassava plants require large amounts of nutrients in the early stages of development, explaining why chemical fertilization promoted favorable conditions for crop growth and yield. According to Corrêa et al. (2016), about $80 \%$ of tuberous roots are formed in the first four weeks after planting, necessitating adequate irrigation and nutrient availability during the growth period.

\section{Hierarchical clustering and principal component analysis}

Hierarchical clustering, using a Euclidean distance of 3 , afforded three groups (Fig. 5A): T2, isolated from T3 and T4, which were grouped together, and $\mathrm{T} 1$, also isolated from the other treatments. Principal component analysis was used to complement hierarchical clustering analysis. Principal component (PC) 1 and PC2 explained $87.77 \%$ of the total variance in the dataset, with PC1 (plant factors) accountable for $63.15 \%$ of the total variance and PC2 (soil carbon) accountable for $24.62 \%$ (Fig. 5B). A strong negative correlation was observed between PC1 and shoot fresh weight, marketable stem diameter, root yield, marketable root yield, total root index, and marketable root index. These variables were important to discriminate the yield indices of NPK-treated plants. PC2 was strongly and positively correlated with soil TOC, explaining the differences between organic fertilizers and other treatments. The control also differed from the other treatments, as revealed by hierarchical cluster analysis.

These results show that, although cassava is a tolerant plant able to grow on acidic soils with low nutrient availability, synthetic fertilizers can markedly increase root yield. Adiele et al. (2020) concluded that cassava yield is greater when using chemical fertilization. Similarly, Alves et al. (2012) reported that chemical fertilizers provide gains in cassava production; however, these inputs are not always available to farmers because of their high costs. Organic fertilizers did not influence yield in the first crop cycle; more time is needed to investigate their effects over a longer period. According to Nascimento et al. (2014), organic fertilizers tend to improve the chemical, physical, and biological attributes of soil.

\section{Material and methods}

\section{Experimental site}

The experiment was conducted on a family farm in the Boa Esperança community $\left(2^{\circ} 44^{\prime} 24.7^{\prime \prime} \mathrm{S} 54^{\circ} 31^{\prime} 33.2^{\prime \prime} \mathrm{W}, 145 \mathrm{~m}\right.$ elevation), PA-370, km 41, Santarém, Pará, Brazil (Fig. 1).

The region has a tropical climate with two well-defined seasons (Köppen classification), a rainy period from December to May and a dry period from June to November (Oliveira et al., 2018). The average annual temperature ranges from 25 to $28{ }^{\circ} \mathrm{C}$, the average relative air humidity is about $86 \%$, and the average annual precipitation is $2,282 \mathrm{~mm}$ (Souza et al., 2019), as depicted in Fig. 2.

\section{Cassava cultivation in the 2017/2018 agricultural year}

The experiment was conducted between March 2017 and July 2018. Cuttings of cassava ( $M$. esculenta) 'Bem-te-vi' were planted at a spacing of $1 \times 1 \mathrm{~m}$ over an area of $980 \mathrm{~m}^{2}$ on yellow Latosol of very clayey texture. Soil samples were collected before planting and analyzed for fertility (Table 1). Soil acidity was corrected by lime application, according to Cravo et al. (2007).

\section{Experimental design}

A randomized block design was used, with four treatments of five blocks, totaling 20 plots of $36 \mathrm{~m}^{2}$ each. Treatments were as follows: T1, unfertilized soil; T2, soil fertilized with NPK fertilizer, according to Cravo et al. (2007); T3, soil fertilized with $3.06 \mathrm{t} \mathrm{ha}^{-1}$ poultry manure; and T4, soil fertilized with $4.44 \mathrm{t} \mathrm{ha}^{-1}$ cattle manure.

\section{TOC analysis}

For TOC determination, 20 composite samples were collected from each experimental plot using a Dutch auger at a depth of $0.0-0.20 \mathrm{~m}$. Samples were air-dried, sieved through 80 mesh sieves, and analyzed by wet oxidation with potassium dichromate in acidic medium (Yeomans \& Bremner, 1988).

\section{Determination of cassava crop characteristics}

Crop characteristics were determined at harvest. The following morphological and agronomic descriptors were analyzed as proposed by Fukuda and Guevara (1998): shoot fresh weight, plant height, marketable stem diameter, root yield, and marketable root yield.

\section{Statistical analysis}

Data were subjected to analysis of variance, and treatment means were compared at the $5 \%$ significance level by Tukey's 
test. After normalization to zero mean and unit standard deviation $(\mu=0, \sigma=1)$, the data were subjected to hierarchical clustering and principal component analysis. Variables with eigenvalues greater than 1.00 were retained, according to the criterion proposed by Kaiser (1958). All statistical analyses were performed using Statistica 7.0 software.

\section{Conclusion}

Organic fertilization led to greater organic carbon accumulation in soil at the end of the crop cycle, resulting in increased TOC levels. NPK fertilizer application provided the best results for shoot fresh weight, whereas, for plant height and stem diameter, NPK and cattle manure were the most effective. Organic fertilizer treatments did not affect marketable or total root yield, but NPK application positively influenced these parameters. Multivariate analyses identified three groups, separating chemical fertilizer, organic fertilizer, and unfertilized treatments.

\section{References}

Adiele JG, Schut AGT, Beuken RPMVD, Ezui KS, Pypers P, Ano AO, Egesi CN, Giller KE (2020) Towards closing cassava yield gap in West Africa: agronomic efficiency and storage root yield responses to NPK fertilizers. Field Crops Res. 253: 111.

Alves AAC. Cassava botany and physiology. In: Hillocks RJ, Thresh JM, Bellotti A. Cassava: biology, production and utilization. New York: Wallingford, UK, 2002. p. 67-89.

Alves RNB, Júnior MSM, Rerreira ER (2012) Doses de NPK na adubação de mandioca (Manihot esculenta $L$,) variedade Paulozinho em Mojú-Pará. Rev Raíz e Amid Trop. 8: 65-70.

Barbieri DM, Júnior JM, Pereira GT, Júnior NLS, Siqueira DS, Panosso AR (2013) Comportamento dos óxidos de ferro da fração argila e do fósforo adsorvido, em diferentes sistemas de colheita de cana-de-açúcar. Revista Bras de Ci do Sol. 37(6): 1557-1568

Barré $P$, Quénéa $K$, Vidal A, Cécillon L, Christensen BT, Katerrer T, Macdonald A, Petite L, Plante AF, Oort FV, Chenu C (2018) Microbial and plant-derived compounds both contribute to persistente soil organic carbon in temperate soils. Biogeochemistry. 140:81-92.

Bezerra CB, Medeiros EV, Silva CAD, Notaro KA, Negreiros AMP, Júnior RS (2019) Non-autoclaved poultry litter and soil are eficiente in controlling Scytalidium lignicola growth, the causal agent of cassava black root. Summa Phytopathol. 45(2): 191-196.

Biratu GK, Elias E, Ntawuruhunga P (2019). Soil fertility status of cassava fields treated by integrated application of manure and NPK fertilizer in Zambia. Environ Syst Res. 8(3): 2-13.

Chenu C, Angers DA, Barré P, Derrien D, Arrouays D, Balesent J (2019) Increasing organic stocks in agricultural soils: knowledge gaps and potential innovations. Soil Til Res. 188:41-52.

Corrêa CV, Gouveia AMS, Evangelista RM, Cardoso All (2016) Carboidratos e proteínas em raízes de batata-doce influenciadas pelo parcelamento do nitrogênio e armazenamento de raízes. Revist. Raíz e Amid Trop. 12(1): 36-44.

Cravo MS, Viégas IJM, Brasil EC. Recomendações de adubação e calagem para o estado do Pará. Belém, PA: Embrapa Amazônia Oriental. 2007. 262 p.
Denardin RBN, Mattias JL, Wildner LP, Nesi CN, Sordi A, Kolling DF, Busnello FJ, Ccerutti T (2014) Estoque de carbono no solo sob diferentes formações florestais, Chapecó-SC. Ciência Florest. 24(1): 59-69.

Falqueto AR, Cassol D, Júnior AMM, Oliveira AC, Bacarin MA (2009) Crescimento e partição de fotoassimilados em cultivares de arroz diferindo no potencial de produtividade de grãos. Bragantina. 68(3): 563-571.

FAO - Organização das Nações Unidas para Alimentação e Agricultura. As estatísticas da FAO Brasil. 2016. [Acesso em: 21 de apr. 2020]. Disponível em: http://www.fao.org/family-farming/detail/en/c/454156/

FUKUDA, W.M.G.; GUEVARA, C.L. Descritores morfológicos e agronômicos para a caracterização de mandioca (Manihot esculenta Crantz). Cruz das Almas: EMBRAPA-CNPMF, 1998, 38p. (EMBRAPA-CNPMF, Documento, 78.)

Glosh A, Bhattacharyya R, Meena MC, Dwivedi BS, Singh G, Agnihotri R, Sharma C (2018) Long-term fertilization effects on soil organic carbon sequestration in an inceptisol. Soil Till Res. 177: 134-144.

Guimarães DG, Prates CJN, Viana AES, Cardoso AD, Santos VS, Matsumoto SN, Novaes QS, Júnior NSC, Lopes SC (2017) Physiological and agronomic characteristics of cassava genotypes. Afr J Agric Sci. 12(5): 354-361.

IBGE - Instituto Brasileiro de Geografia e Estatística. Levantamento sistemático da produção agrícola. 2020. [Acesso em: 21 de apr. 2020]. Disponível em: https://www.ibge.gov.br/estatisticas/economicas/agricult ura-e-pecuaria/9201-levantamento-sistematico-daproducao-agricola. $h \mathrm{tml} ?=\& \mathrm{t}=$ resultados

Kaiser HF (1958) The varimax criterion for analytic rotation in factor analysis. Psychometrika. 23: 187-200.

Kravchencko AN, Guber AK (2017) Soil pores and their contributions to soil carbon processes. Geoderma. 287:3139.

Lal R (2016) Soil health and carbon management. Food Energy Sec. 5(4): 212-222.

Leite LFC, Mendonça ES, Neves JCL, Machado PLOA, Galvão JCC (2003) Estoques totais de carbono orgânico e seus compartimentos em argissolo sob floresta e sob milho cultivado com adubação mineral e orgânica. Revista Bras de C. do Solo. 27(5): 821-832.

Lützow MV, Knabner IK, Ekschimitt K, Matzner E, Guggenberger G, Marschner B, Flessa H (2006) Stabilization of organic matter in temperate soils: mechanisms and other relevance under diferente soil conditions-a review. Eur J Soil Sci. 57: 426-445.

Malta AO, Pereira WE, Torres MNN, Malta AO, Silva ES, Silva SIA (2019) Atributos físicos e químicos do solo cultivado com gravioleira, sob adubação orgânica e mineral. Revista Pes Agr. 2(1): 11-23.

Mathias L, Kabambe VH (2015) Potencial para aumentar a produção de mandioca através da aplicação de adubo e fertilizantes: resultados do Bunda College, Central Malawi. Afr J Plant Sci. 09(5): 228-234

Nascimento JML, Santos MRB, Queiroz MAA, Yano-melo AM (2014) Desenvolvimento vegetativo e associação micorrízica em plantas de mandioca adubadas com resíduo agroindustrial. Sem: Ci Agr. 35(2): 727-734.

Odedina JN, Odedina AS, Ojeniyi SO (2011) Efeito de tipos de esterco no crescimento e rendimento de mandioca (Manihot esculenta Crantz). Researcher. 3(5): 01-08.

Oliveira LL, Sousa D, Barreto NJC, Santos GP, Almeida RM (2018) Ilha de calor urbana:diagnóstico como ferramenta 
de gestão ambiental urbana para a cidade de Santarém (PA). Revista Ib Am De Ci Amb. 9(6): 428-443.

Otsubo AA, Brito OR, Passos DP, Araújo HS, Mercante FM, Otsubo VHN (2012) Formas de preparo de solo e controle de plantas daninhas nos fatores agronômicos e de produção de mandioca. Semina: Ciênc Agr. 33(6): 2241-2246.

Pacheco RIL, Macias MP, Campos FCF, Izquierdo AJR, Izquierdo GAR (2020) Agronomic and physiological evaluation of eight cassava clones under water deficit conditions. Revist da Fac de Agron. 73(1): 9109-9119.

Pereira GAM, Lemos VT, Santos JB, Ferreira EA, Silva D, Oliveira MC, Menezes CWG (2012) Crescimento de mandioca e plantas daninhas em resposta à adubação fosfatada. Revist Ceres. 59(5): 716-722.

Pimentel ML, Reis IMS, Portela VS, Romano MLPC, Vildoso CIA, Gasparin E, Sia EF (2020) Effect of different sources of fertilization on chemical properties of soil under cassava cultivation in western Pará, Brazil. J Agric Sci. 12(9): 106114.

Ramos NP, Yamaguchi CS, Pires AMM, Rossetto R, Possenti RA, Packer AP, Cabral OMR, Andrade CA (2016) Decomposição de palha de cana-de-açúcar recolhida em diferentes níveis após a colheita mecânica. Pesq Agrop Bras. 51(9): 1492-1500.

Rós AB, Hirata ACS, Narita N (2013) Produção de raízes de mandioca e propriedades química e física do solo em função de adubação com esterco de galinha. Pesq Agrop Trop. 43 (3): 247-254.

Rós AB, Narita N, Hirata ACS, Creste JE (2020) Effects of limestone and organic fertilizer on cassava yield and on chemical and physical soil properties. Ver Cer. 67(1): 023029.

Senesi GS, Neto LM, Boas PRV, Nicolodelli G, Milori DMBP (2016) Laser-based spectroscopic methods to evaluate the humification degree of soil organic matter in whole soils: a review. J Soil Sedim. 18(2018): 1292-1302.

Shah GM, Rashid MI, Shah GA, Groot JCJ, Lantinga EA (2013) Mineralization and herbage recovery of animal manure nitrogen after application to various soil types. Plant Soil. 365:69-79.

Silva DCO, Alves JMA, Uchôa SCP, Souza AA, Barreto GF, Silva CN (2017) Curvas de crescimento de plantas de mandioca submetidas a doses de potássio. Rev de Cie Agr. 60(2): 158165.
Soares MRS, José ARS, Nunes RTC, Silva RA, Caetano APO Oliveira DS, Nolasco CA, Rampazzo MC (2019) Períodos de interferência de plantas infestantes na cultura da mandioca, submetida ou não a adubação com NPK, em Vitória da Conquista-Ba. Revist. de Ciênc Agr. 42(1): 237 247.

Souza FVA, Ribeiro SCA, Silva FL, Teodósio AEMM (2019) Resíduos da mandioca em agroindústrias familiares no Nordeste do Pará. Revista Verd. 14(1): 92-98.

Souza KA, Leal SR, Santos JL, Sousa JN, Maestri MP, Sousa SF (2019) Florística e avaliação qualitativa da espécie Mangifera Indica L. nas praças de Santarém, Pará. Revista Ib Am de Ci Amb. 10(2): 351-361.

Suárez L, Mederos V (2011) Apuntes sobre el cultivo de la yuca (Manihot esculenta Crantz) current trends. Cult Trop. 32(3): 27-35.

Tironi LF, Uhlmann LO, Streck NA, Samboranha FK, Freitas CPO, Silva MR (2015) Desempenho de cultivares de mandioca em ambiente subtropical. Bragantina. 74(1): 5866.

Utsumi Y, Utsumi C, Tanaka M, Há CV, Takahashi S, Matsui A, Matsunaga TM, Matsunaga S, Kanno Y, Seo M, Okamoto Y, Moriya E, Seki M (2019) Acetic acid treatment enhances drought avoidance in cassava (Manihot esculenta Crantz). Front Plant Sci. 10(521): 1-12.

Vieira CR,Weber OLS, Jardini DC (2015) Distribuição do carbono orgânico e do nitrogênio total nas frações granulométricas de um latossolo sob diferentes tipos de vegetações. Revist de Est Amb. 17(1): 43-53.

Vieira LJ, Filho LFQT, Souza FVD, Alves AAC, Oliveira EJ (2013) Development of interspecific hybrids of cassava and paternity analysis with molecular markers. J Agri Sci. 151(6): 849-861.

Wiesmeier M, Urbanski L, Hobley E, Lang B, Lutzow MV, Spiotta EM, Wesemael BV, Rabot E, Lieb M, Franco NG, Wollschlager U, Vogel HJ, Knabner IK (2019) Soil organic carbon storage as a key function of soils - A review of drivers and indicators at various scales. Geoderma. 333: 149-162.

Yeomans, J. C.; Bremner, J. M. A rapid and precise method for routine determination of organic carbon in soil. Communications Soil Science and Plant Analysis, v. 19, p.1467-1476, New York 1988. 